\title{
Two white-flowered Draba (Brassicaceae) species from Korean flora
}

\author{
Hoe-Won Kim and Ki-Joong Kim \\ Division of Life Sciences, Korea University, Seoul 136-701, Korea \\ (Received 20 January 2015; Accepted 16 February 2015)
}

\section{한국의 흰꽃 피는 꽃다지속 (십자화과) 두 종}

\author{
김회원 · 김기중* \\ 고려대학교 생명과학대학 생명과학부
}

\begin{abstract}
Draba ussuriensis Pohle is reported from Mt. Baekdu in this paper as a new member of Korean flora. D. ussuriensis is a white-flowered perennial herb and similar to Draba mongolica Turczaninow. However, D. ussuriensis differs from Draba mongolica Turczaninow in a number of characters. The stems and pedicels of $D$. mongolica are covered by dense trichomes, while those of $D$. ussuriensis are glabrous or glabrescent. $D$. ussuriensis has fewer cauline leaves compared to D. mongolica. The Korean name of $D$. ussuriensis Pohle stems from the specific epithet of its scientific name. In addition, $D$. mongolica is a new name, replacing the previously misidentified names of $D$. glabella Pursh, $D$. daurica DC., D. incana L., and D. nipponica Makino in several different studies. We corrected the name based on a comparative morphological study of specimens collected from Mt. Baekdu and Gwanmobong and related species. As a result, Korean Draba consists of three species: two white-flowered species and one yellow-flowered D. nemorosa $\mathrm{L}$.
\end{abstract}

Keywords: Draba ussuriensis, D. mongolica, Brassicaceae, Mt. Baekdu, newly recorded species in Korea

적 요: 한국의 십자화과 꽃다지속 식물 우수리꽃다지 (Draba ussuriensis Pohle)를 백두산에서 새로이 발견 하여 보고한다. 본종의 특징은 꽃이 흰색이고 다년생인 점이 구름꽃다지(Draba mongolica Turczaninow)와 유 사하지만, 줄기와 과경에 털이 없고 경엽의 수가 작은 점이 구름꽃다지와 다르다. 국명은 학명의 종소명에서 유래한 이름을 사용하였다. 또한 과거 백두산 및 관모봉 지역에서 자라는 구름꽃다지는 D. incana L., D. glabella Pursh, D. nipponica Makino, D. daurica DC. 등으로 혼돈하여 알려졌다. 그러나 백두산 및 관모봉에 서 채집한 표본들을 조사하고 유연종들과 비교분석한 결과 D. mogolica로 밝혀져 그간 잘못 사용된 학명을 바로 잡았다. 따라서 한국산 꽃다지속 식물은 흰꽃 피는 두 종과, 노란색 꽃이 피는 꽃다지를 포함하여 총 3 종이 분포한다.

주요어: 우수리꽃다지, 구름꽃다지, 십자화과, 백두산, 한국 미기록 종

The genus Draba L. consists of approximately 380 species and it is the largest genus in the family Brassicaceae (Al-Shehbaz et al., 2010). The majority of species are distributed in the arctic, alpine, and subalpine areas of northern hemisphere (Tolmachev, 1970; Zhou et al., 2001;

\footnotetext{
*Author for correspondence: kimkj@korea.ac.kr
}

http://www.pltaxa.or.kr

Copyright (C) 2015 the Korean Society of Plant Taxonomists
Tkach et al., 2008; Jordon-Thaden et al., 2010). However, the distribution ranges of several species are also extended to the Andean mountains of South America (Al-Shehbaz et al., 2010). Many species complexes make it difficult to recognize the species boundaries because of agamospermy and continuing variation patterns of the key characters (Mulligan and Findlay, 1970). In addition, frequent hybridization events, often followed by polyploidization (Mulligan, 1970) and sometimes apomixis (Grundt at al., 2004), complicate the evolutionary history of Draba. 
Molecular investigations for a better understanding of the systematics and phylogeny of this complex genus is largely incompleted because of poor taxon samplings (Koch and Al-Shehbaz, 2002; Jordon-Thaden et al., 2010).

Despite the large numbers of species in the temperate, subarctic, arctic, and alpine regions of the northern hemisphere, only two species, D. dahurica (or D. glabella) and $D$. nemorosa, have been recognized from Korean flora for long times (Mori, 1922; Oh, 2007). However, various different species names are applied to the white flowered Draba species. For example, three independent names are listed in the National Standard Plant Name Index of Korea (by National Arboretum, http://www.nature.go.kr/newkfsweb/ $\mathrm{html})$. The recognition of the two species is easy because the former species shows white colored flowers while the latter species has yellow colored flowers. In contrast to the previous description of the Korean Draba, we collected repeatedly two distinct types of white flowered Draba from Mt. Baekdu for the last several years. Therefore, we revised the genus Draba for the Korean flora in this paper. As a result, we reported a new white flowered Korean Draba species as an unreported species. In addition, we also corrected a misused scientific name for the other white flowered Draba species for Korean flora.

\section{Taxonomic Treatment}

Draba ussuriensis Pohle, Izv. Imp. Bot. Sada Petra Velikago. 14: 470. (1914) (Fig. 1)

Korean name: U-su-ri-kkot-da-ji 우수리꽃다지

Perennial herbs, 6-14 cm tall. Stems more or less loosely cespitose, a few to several branched at base, ultimate branches terminated in rosettes and covered with leaf remains of previous years. Basal leaves rosulate, persistent; petiole up to $5 \mathrm{~mm}$, ciliate with simple trichomes; leaf blade oblongspatulate, $7-18 \mathrm{~mm} \times 2-5 \mathrm{~mm}$, densely pubescent with subsessile stellate trichomes with 1 or 2 rays, base attenuate, margin entire or 1-3 toothed on each side, ciliate with simple trichomes, apex obtuse to acute. Each stem erect, simple, sparsely pubescent with stellate trichomes, glabrous distally. Cauline leaves 1 to 3 , sessile; leaf blade ovate to oblong, 6$12 \times 2-5 \mathrm{~mm}$, pubescent as basal leaves, base obtuse, margin entire or 1-3-toothed, apex acute. Racemes 7-17-flowered, rather loose, spreading, elongated in fruit. Fruiting pedicels 4$13 \mathrm{~mm}$, straight, slender, glabrous, almost perpendicular to axis in fruit. Sepals ovate-oblong, $1.8-2.5 \times 0.9-1.3 \mathrm{~mm}$, erect, abaxially sparsely pubescent with short simple hairs, base of lateral pair not saccate, margin membranous. Petals white,

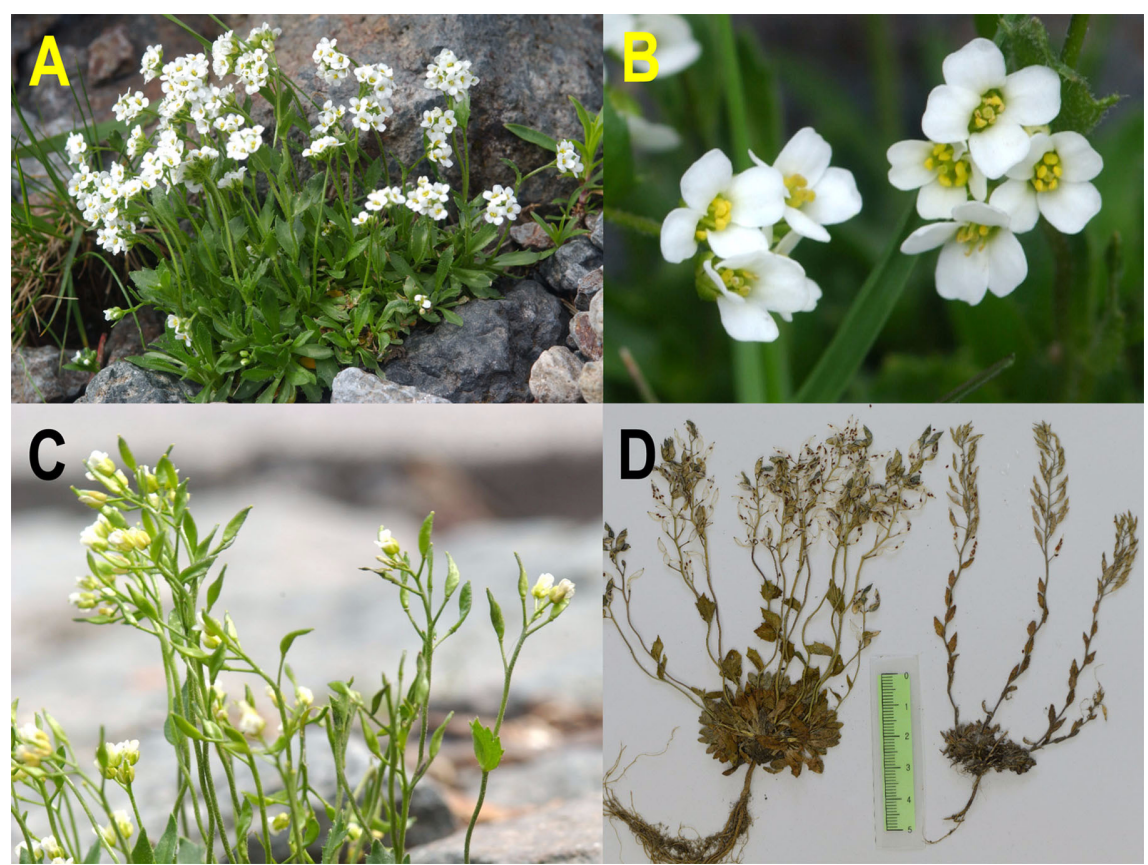

Fig. 1. A. Flowering stage of D. ussuriensis Pohle in Mt. Baekdu. B. Floral details of D. ussuriensis. The white petals are rounded or slightly emarginated on the center of tips. C. Slightly twisted fruits of D. ussuriensis. The fruits are usually twisted one or half turns. It is more prominent at the latter stages of fruit development. D. Comparison of fruiting specimens of D. ussuriensis (left) and D. mongolica Turczaninow (right). Cauline leaves of $D$. mongolia are smaller than those of $D$. ussuriensis and more or less appressed to the axis. The numbers on scale bar is $\mathrm{cm}$. 
narrowly obovate, $4-6 \times 2-3 \mathrm{~mm}$, apex subemarginate. Filaments 1.5-2.5 mm; anthers ovate, $0.2-0.3 \mathrm{~mm}$. Ovules $12-$ 24 per ovary. Fruit oblong-ovate to elliptic, $5-10 \times 2-2.5 \mathrm{~mm}$, not inflated, latiseptate, usually half to 1 turn twisted or rarely untwisted; valves glabrous, not veined, base and apex acute; style ca. $1 \mathrm{~mm}$. Mature seeds light brown, ovate, 1.0-1.2 $\times 0.5-$ $0.6 \mathrm{~mm}$. Flowering at June and fruiting at July. [Chromosome number $2 \mathrm{n}=16,32]$.

Habitat: Sunny rock cliffs, near hot springs, alpine moss plains, altitudes 1900-2600 m.

Distribution: Mt. Baekdu, Yanggang-do, North Korea, [Sakhalin and nearby Tatar Strait area, Russia].

Specimen examined: Mt. Baekdu, Yanggang-do, K.-J. Kim and H.-L. Lee 2002-0801 (KUS), K.-J. Kim, M.-J. Song and H.-J. Bang 2004-1168 (KUS), K.-J. Kim, J.-S. Kim and J. H. Yuan 2006-0957 (KUS [4 sheets])

Notes: Draba ussuriensis is very rare in Korea and is collected in the three different places of Mt. Baekdu including two places in the Chinese territory and one place in the North Korean territory. The Korean name of $D$. ussuriensis Pohle is adopted from the specific epithet of scientific name. We transplanted the five individuals of this species from Mt. Backdu to the green house of Korea University in 2006 and grew the plants for two years. The greenhouse growing plants showed high phenotype plasticity in vegetative characteristics. One of the distinctive observed differences in the transplants was highly branched and long creeping stems at the base of plants. Rosulated basal leaves in the transplants were also longer and more slender than original habitat plants. The interval between flowers on stem also elongated in the transplants. However, the flower and fruit characteristics of the transplants were almost unchanged during the greenhouse growing experiments. D. ussuriensis is white flowered perennial herbs and these characristics similar to D. mongolica Turczaninow. However, D. ussuriensis is different from $D$. mongolica in the numbers of characters. The stems and pedicels of $D$. mongolica are covered by dense trichomes, while those of $D$. ussuriensis are glabrous or glabrescent. D. ussuriensis also has less numbers of cauline leaves compared to that of D. mongolica (Fig. 1). In addition, D. ussuriensis shows limited distribution on the high altitude of Mt. Baekdu, Sakhalin and nearby Tatar Strait area while D. mongolica shows wider distribution ranges in the high mountains of North Korea, adjacent Northeastern China, Mongolia, and Far Eastern Russia.

Draba mongolica Turczaninow, Bull. Soc. Imp. Naturalistes Moscou 15: 256 (1842).
D. incana L. var. multicaulis Regel et Tilling (Mori, T. 1921, An Enumeration of Plants hitherto known from Corea, 174 p., Chung, T. H. 1956, Korean Flora, Vol. II, Herbaceous Plants, 257 p.).

Draba nipponica Makino (Park M. K. 1949. An Enumeration of Korean Plants, 89 p.).

Draba daurica DC. var. meyeri Busch (Lee, C.-B. 1980, Illustrated Flora of Korea, 395p., Lee W.-C. 1996. Lineamenta Florae Koreae 411 p.).

Draba daurica DC. var. ramosa Pohl et Bush (Lee W.-C. 1996. Lineamenta Florae Koreae 411 p., Im R. J. 1997. Flora Coreana Vol. 3, 64 p.).

D. glabella Pursh (Oh, B. Y. 2007. The Genera of Vascular Plants of Korea, Ed. Park, C.-W., 450 p.).

Korean name: Gu-rum-kkot-da-ji 구름꽃다지

Biennial or perennial herbs, 5-15 cm tall. Stems more or less cespitose, a few to several branched at base, ultimate branches terminated in rosettes and covered with leaf remains of previous years. Basal leaves rosulate; petiole absent or rarely up to $1.0 \mathrm{~cm}$; leaf blade lanceolate, $8-15 \times 1-5 \mathrm{~mm}$, tomentose with sessile, 2-4-rayed stellate trichomes the rays of which with 1 or 2 lateral branches, base attenuate to cuneate, margin entire or dentate, not ciliate, apex acute. Each stem simple or rarely branched, tomentose with subsessile stellate trichomes. Cauline leaves 6 to 14, sessile, more or less appressed to axis; leaf blade ovate, oblong, or elliptic, 6-15 × 2-8 mm, pubescent as basal leaves, base cuneate to obtuse, margin entire or 1-6toothed on each side, not ciliate at base, apex acute. Racemes 7-20-flowered, ebracteate or lowermost flowers bracteate, more or less appressed to axis, elongated in fruit. Fruiting pedicels $2-5 \mathrm{~mm}$, straight or often divaricate, tomentose all around with subsessile, stellate trichomes, more or less appressed to axis. Sepals oblong, 1.0-1.6 $\times 0.5-1.0 \mathrm{~mm}$, erect, abaxially pilose, base of lateral pair not saccate, margin membranous. Petals white, spatulate, 2-3.5 × 1-1.5 mm, apex subemarginate or rounded. Filaments $1.0-2.0 \mathrm{~mm}$; anthers ovate, $0.1-0.2 \mathrm{~mm}$. Ovules $12-20$ per ovary. Fruit narrowly oblong-ellipsoid to lanceolate-linear, 5-8 $\times 1.5-$ $2.5 \mathrm{~mm}$, erect, latiseptate, flat or twisted to 1 turn; valves tomentose or glabrous, obscurely veined, base obtuse, apex acute or acuminate; style $0.1-0.3 \mathrm{~mm}$. Seeds brown, ovate, $0.9-1.1 \times 0.5-0.6 \mathrm{~mm}$. Flowering at June and fruiting at July and August.

Habitat: Sunny rock cliffs, near high mountain river banks, alpine moss plains, altitudes $1700-2400 \mathrm{~m}$.

Distribution: Mt. Baekdu, Yanggang-do and Gwanmobong, Hamgyeongbuk-do, North Korea, [North Eastern to Central China, Mongolia, Far Eastern Russia]. 
Table 1. The diagnostic character differences among the five closely related white flowered Draba species. Data were generated from the direct measurements of specimens and supplemented from the literature (Tolmachev, 1970; Walters and Akeroyd, 1993; Zhou et al., 2001; Al-Shehbaz et al., 2010).

\begin{tabular}{|c|c|c|c|c|c|}
\hline Character & D. ussuriensis & D. mongolica & D. incana & D. hirta* & D. glabella \\
\hline Habit & Perennial & Bi-Perennial & Bi-Perennial & Perennial & Perennial \\
\hline Heights (cm) & $6-14$ & $5-15$ & $2-35$ & $35-40$ & $10-35$ \\
\hline No. of cauline leaves & $1-3$ & $6-14$ & $8-50$ & $1-6$ & $2-17$ \\
\hline $\begin{array}{l}\text { Attachment of cauline leaves } \\
\text { on axis }\end{array}$ & Spreading & Appressed & Appressed & Spreading & Spreading \\
\hline Size of basal leaves (L/W, mm) & $7-18 / 2-5$ & $8-15 / 1-5$ & $7-14 / 2-4$ & $8-40 / 1.5-8$ & $10-35 / 2-8$ \\
\hline $\begin{array}{l}\text { Trichomes on upper stems } \\
\& \text { pedicels }\end{array}$ & Glabrous & Densely pubescent & Densely pubescent & Densely pubescent & Usually glabrous \\
\hline $\begin{array}{l}\text { Trichome types on upper } \\
\text { stems \& pedicels }\end{array}$ & NA & Branched hairs & Simple hairs & $\begin{array}{l}\text { Branched or } \\
\text { stellate hairs }\end{array}$ & NA \\
\hline Nos. of flowers/stem & $7-17$ & $7-20$ & $10-40$ & $4-36$ & $8-26$ \\
\hline Petal lengths (mm) & $4-6$ & $2-3.5$ & $3.5-4.5$ & $4-5.5$ & $4-5.5$ \\
\hline Pedicel lengths (mm) & $4-13$ & $2-5$ & $2-5$ & $2-5$ & $3-10$ \\
\hline Chromosome nunbers (2n) & 16,32 & NA & 32 & 64 & 64,80 \\
\hline Main distribution ranges & $\begin{array}{l}\text { F.E. USSR } \\
\& \text { N.E. China }\end{array}$ & $\begin{array}{c}\text { F.E. USSR, Sahaline, } \\
\text { Mongolia } \\
\text { \& N.E. China }\end{array}$ & W. \& C. Europe & N. Europe & N. America \\
\hline
\end{tabular}

Specimen examined: Mt. Baekdu, Yanggang-do, K.-J. Kim and H.-L. Lee 2002-0800 (KUS [4 sheets]); Gwanmobong, Hamgyeongbuk-do, Do B.-S., July 16, 1936 (SNU 4155), Do B.-S., July 17, 1936 (SNU 4156), Do B.-S., July 19, 1936 (SNU 4154), Do B.-S., July 20, 1936 (SNU 4153, 4157).

Notes: Draba mongolica had been recoded by Mori (1922) as a member of Korean flora. Mori (1922) used the name $D$. incana L. var. multicaulis Regel et Tilling. Various scientific names were adopted for this species since then. Oh (2007) recently adopted the name of D. glabella for this species (Walters and Akeroyd, 1993). We compared the D. glabella specimens from the University Alaska Museum (Batten, A. R. and J. C. Dawe 78-134; Murray, D. F. 6690a; Parker, C. 904) and from the Canadian Museum of Nature (Gillespie 7538, 10182, 10166, 10204, 10214; Sarela 1436; Bennett 06-363; Gillett 18682) to the Korean D. mongolica specimens. The basal and cauline leaf morphologies were markedly different between two species. In addition, the stem of $D$. glabella was much taller than that of $D$. mongolica. The pedicel length of $D$. glabella was much longer than that of D. mongolica, too. Therefore, we corrected the misidentified names to be the D. mongolica. D. glabella is distributed mainly in Alaska and arctic Canada. It is a rare plant species in New England and other regions of U.S.A. (Allard, 2004; Al-Shehbaz et al., 2010). D. mongolica is different from $D$. incana L. or $D$. hirta L. in the shapes of cauline leaves, and also the trichome types and distribution patterns on the leaves and stems. The differences among these species are summarized in Table 1.

\section{Key to the Korean species of Draba}

1. Plants annuals, flowers yellow, fruiting pedicels usually longer than $1 \mathrm{~cm}$ ……………… D. nemorosa 꽃다지

1. Plants biannuals or perennials, flowers white, fruiting pedicels usually shorter than $0.7 \mathrm{~cm}$

2. Stems and fruiting pedicels glabrous or glabrescent at upper distal half, cauline leaves 1-4

D. ussuriensis 우수리꽃다지

2. Stems and fruiting pedicels tomentose throughout, cauline leaves 6-14

D. mongolica 구름꽃다지

\section{Acknowledgements}

This work is supported by the Eco-Innovation project of the Ministry of Environment (416-111-007), Korea. The DNA materials of two Draba species (PDBK 2002-0800, 2002-0801, 2004-1168, 2006-0957) are available from the Plant DNA Bank in Korea. 


\section{Literature Cited}

Allard, D. J. 2004. Draba glabella Pursh (Smooth Whitlow-grass), conservation and research plan for New England. New England Wild Flower Society, Framingham, Massachusetts, USA. Pp. 120.

Al-Shehbaz, A., M. D. Windham and R. Elven. 2010. Draba. In Flora of North America. Vol. 7. D. E. Boufford et al. (eds.). Oxford Univ. Press, New York and Oxford. Pp. 234-347.

Grundt, H. H., M. Popp, C. Brochmann and B. Oxelman. 2004. Polyploid origins in a circumpolar complex in Draba (Brassicaceae) inferred from cloned nuclear DNA sequences and fingerprints. Molecular Phylogenetics and Evolution 32: 695710.

Jordon-Thaden, I., I. Hase, I. Al-Shehbaz and M. A. Koch. 2010. Molecular phylogeny and systematics of the genus Draba (Brassicaceae) and identification of its most closely related genera. Molecular Phylogenetics and Evolution 55: 524-540.

Koch, M. and I. A. Al-Shehbaz. 2002. Molecular data indicate complex intra- and intercontinental differentiation of American Draba (Brassicaceae). Annals of the Missouri Botanical Garden 89: 88-109.

Mori, T. 1922. An Enumeration of Plants hitherto known from Corea. The Government of Chosen, Seoul. Pp. 174-175.
Mulligan, G. A. 1970. Cytotaxonomic studies of Draba glabella and its close allies in Canada and Alaska. Canadian Journal of Botany 48: 1431-1437.

Mulligan, G. A. and J. N. Findlay. 1970. Sexual reproduction and agamospermy in the genus Draba. Canadian Journal of Botany 48: 269-270.

Oh, B.-U. 2007. Brassicaceae. In The Genera of Vascular Plants in Korea. Park, C.-W. (ed.), Academic Press, Seoul. Pp. 427461.

Tkach, N. V., M. Rser and M. H. Hoffmann. 2008. Range size variation and diversity distribution in the vascular plant flora of the Eurasian Arctic. Organisms, Diversity \& Evolution 8: 251-266.

Tolmachev, A. I. 1970. Draba. In Flora of the U.S.S.R. Vol. 8. V. L. Komarov (ed.), R. Lavoott (transl.). Keter Press, Jerusalem. Pp. 276-337.

Walters, S. M. and J. R. Akeroyd. 1993. Draba. In Flora Europaea, Vol. 1. T. G. Tutin et al. (eds.). Cambridge Univ. Press, Cambridge. Pp. 372-377.

Zhou, T.-J., L. I. Lu, G. Yang and A. Al-Shehbaz. 2001. Draba. In Flora of China. Vol. 8. Wu, Z. Y. and P. H. Raven (eds). Science Press and Missouri Botanical Garden Press, Beijing and St. Louis. Pp. 66-86. 